\title{
Growth Action of Land Utilization Pattern in Jalna District of Maharashtra State, India
}

\author{
A.A. Kharat, K.V. Deshmukh and R.D. Shelke* \\ Department of Agricultural Economics, Vasantrao Naik Marathwada Krishi Vidyapeeth \\ Parbhani, India \\ *Corresponding author
}

\section{Keywords}

Growth action, Land utilization pattern gross cropped area, Waste land

Article Info

Accepted:

15 April 2019

Available Online:

10 May 2019

\section{A B S T R A C T}

The present study examines the growth action of land utilization pattern in the Jalna in Maharashtra. Using data from 2002-03 to 2016-17, linear and compound growth rate of land utilization pattern in Jalna District was estimated for each period to study the growth performance. In the District, gross cropped area occupies major portion in total geographical area of the state followed by net sown area and forest area. Despite of this, area under current fallow, other fallow occupies prominent portion in total area. Area under the fallow is increasing. Hence importance is given to prevent converting cropped area to waste land. The study suggests farmers to make use of available resource efficiently to convert cultivable waste land and fallow land into farm land.

\section{Introduction}

Land and water are the crucial natural resources for any development activity. Consequently, access to land and control over its uses were the prime sources of conflict within and between communities throughout human history. Like any other resource land has two dimensions, viz., quality and quantity, and both of these crucial aspects are under serious threat. Though technological progress in agriculture and agricultural intensification have mitigated the demand for land for non-agricultural purposes are posing a serious challenge to both researchers and policy makers. Intensive agriculture coupled with large-scale irrigation projects without utilized or unutilized. For sustainable utilization of the land ecosystems, it is essential to know the natural characteristics, extent and location, its quality, productivity, suitability and limitations of various land uses.

Recognizing the important role of agriculture in the economic development of country, fiveyear plans assign high priority to agricultural development. Agriculture has been the major source of livelihood in India since the primordial age. Invent of Moghals followed 
by British did not change the situation to the desired level. Agriculture remained totally primitive, deteriorative and turbulent. The deficiency of food grains had lead to witnessing of a number of horrible families. The agriculture sector in many developing countries could not move ahead because of large number of physical, natural, economical, social, political and human factors. Since, the post-independence period, several measures have taken to swing-up agricultural sector. The first five year plan allotted 31 per cent of its total investment on agriculture and allied activities in Jalna district area barren and uncultivable land, Net sown area use shows increase in percentage change with positive sign. Area under forest, permanent pastures, area sown more than once gross cropped shows decrease in percentage change. It clearly shows that fallow land, land under non-agricultural use should be used properly to improve land utilization pattern of the state. In present study a comparison is done to analyze percentage change in area under Land utilization pattern for two different periods and growth rates were identified for the same period. The main objective of this study is to change the land utilization pattern.

\section{Materials and Methods}

In the present study, Linear Growth Rate (LGR) and Compound Growth Rate (CGR) were estimated for each period to study the growth LUP. For studying the growth rate in land utilization pattern, linear growth rate was estimated by using following linear functions.

$Y=a+b x+e$

Where

$\mathrm{Y}=$ Dependent variable for which growth rate is estimated

$\mathrm{a}=$ Intercept/Constant

$\mathrm{b}=$ Regression/trend coefficient $\mathrm{x}=$ Period in years

$\mathrm{e}=$ Error term with zero mean and constant variance.

Compound Growth Rate was then estimated by using the following equation:

$\mathrm{Y}=\mathrm{a} \cdot \mathrm{b}^{\mathrm{x}}$

$Y=$ Dependent variable for which growth rate is estimated

$\mathrm{a}=$ Intercept or constant

$\mathrm{b}=$ Trend $/$ Regression coefficient

$\mathrm{x}=$ Period in years

$b=(1+r)$

where, $r=$ is compound growth rate

C.G.R. $=($ antilog of b-1) $\times 100$

The necessary data for the selected cereals crops was purely based on secondary sources and it was collected from various issues of Statistical Hand Book of Maharashtra, Season and Crop report of Maharashtra.

To work out triennium averages for base period i.e., 2002-03, period considered were 2000-01, 2001-02, 2002-03 and for end period i.e., 2016-17, period for triennium considered were 2014-15, 2015-16, 2016-17 simple arithmetic averages, percentages of selected parameters of development were used for the comparison of situation in Maharashtra over three period of time.

Time period I, II and III represents time series data for 2002-03 to 2008-09, 2010-11 to 2016-17 and 2002-03 to 2016-17 respectively. The present study examines the growth performance of Land Utilization Pattern in Maharashtra State. Table 1 reports the Land utilization pattern for the period of 2002 to 2016-17. It reveals that area under current fallow is constantly increasing throughout the 
period and area sown more than once is decreasing. Gross cropped area of the state is also declining. Area under forest is decreasing but change is minute when compared to other particulars.

\section{Results and Discussion}

\section{Land utilization pattern of jalna district of Maharashtra (2002-03 to 2016-17)}

Land under non-agricultural use is increasing eminently for the entire study period. There is prominent decrease in area sown more than once. Area under permanent pasture is decreasing, but in meager level for every year, when compared to other changes. Forest area of the state also started to diminish. Due to change in climate, unavailability of water, labour and resources area under agriculture is decreased.

Gross Cropped Area of the state declined from 85.76 per cent to 78.91 per cent of the total geographical area. Likewise net sown area also declined from 80.09 per cent to 80.16 per cent of total geographical area. Land utilization pattern of the state for the study period is given in Table 1 .

\section{Percentage change of Land utilization pattern for the period 2002-03 to 2016-17}

Due to unavailability of resources at needed time net sown area of the state has reduced and its percentage change is reduced with negative growth. Similarly area under permanent pastures, area sown more than once and gross cropped area, cultivable waste land shown change in percentage with negative growth. This leads to positive change in Barren and uncultivable land and Net Sown area (Table 2).

\section{Growth rates}

The linear and compound growth rate of the parameters were worked out and presented in Table 3. The average area under forest and barren, uncultivable land were significant for entire working period. Area under land under non-agricultural use was non significant at 1 $\%$ for period I and overall period. The average area under current fallow had been significant at $1 \%$ for I, II and overall period. The gross cropped area for period II and overall period was non significant at $1 \%$. The average area under cultivable waste land, land under the non agriculture, land under misc trees, grooves not included in area sown, area sown more than once were non-significant for overall period. Gross cropped area for state has been decreased significantly in both linear and compound growth rate. It had been decreased from -23.2 to 0.57 per cent in linear growth and -25 to 1.43 per cent in compound growth rate.

The dynamics of land use pattern in the state over the last twenty years reveals that there was a significant decline in the area under cultivable wastes and barren land, area sown more than once, gross cropped area, permanent pastures while there was a sharp increase in land under non-agricultural use, cultivable waste land, land under misc trees, grooves not included in net area sown.

The study reveals that there has been a significant reduction in the area under common lands mainly because of the diversion of these lands for nonagricultural purposes. Stabilization of irrigated acreage is perhaps a more important step than the expansion of irrigation so as to better utilize land resources. 
Table.1 Land utilization pattern of Jalna in Maharashtra (2002-03 to 20016-17) (Area in ha)

\begin{tabular}{|c|c|c|c|c|c|c|c|c|c|c|}
\hline Year & Forest & $\begin{array}{c}\text { Barren and } \\
\text { uncultivable } \\
\text { land }\end{array}$ & $\begin{array}{l}\text { Land under } \\
\text { non- } \\
\text { agricultural } \\
\text { use }\end{array}$ & $\begin{array}{l}\text { Cultivable } \\
\text { waste land }\end{array}$ & $\begin{array}{c}\text { Permanent } \\
\text { pastures }\end{array}$ & $\begin{array}{l}\text { Current } \\
\text { fallow }\end{array}$ & $\begin{array}{l}\text { Other } \\
\text { fallow }\end{array}$ & $\begin{array}{l}\text { Net sown } \\
\text { area }\end{array}$ & $\begin{array}{c}\text { Area } \\
\text { sown } \\
\text { more } \\
\text { than } \\
\text { once }\end{array}$ & $\begin{array}{c}\text { Gross } \\
\text { cropped } \\
\text { area }\end{array}$ \\
\hline 2002-03 & 10100 & 14400 & 71200 & 80900 & 41100 & 84000 & 48500 & 531000 & 13200 & 663000 \\
\hline 2003-04 & 10100 & 14400 & 71200 & 80900 & 41100 & 84000 & 48500 & 531000 & 13200 & 663000 \\
\hline 2004-05 & 10100 & 14400 & 71200 & 80900 & 41100 & 84000 & 48500 & 531000 & 13200 & 663000 \\
\hline 2005-06 & 10100 & 14400 & 71200 & 80900 & 41100 & 84000 & 48500 & 511000 & 13200 & 663000 \\
\hline 2006-07 & 10100 & 15500 & 71200 & 81200 & 42200 & 76000 & 48500 & 511000 & 13200 & 663000 \\
\hline 2007-08 & 10100 & 15500 & 71000 & 81200 & 42200 & 76000 & 48500 & 511000 & 13200 & 663000 \\
\hline 2008-09 & 9450 & 15500 & 71000 & 81200 & 42200 & 76000 & 45300 & 501000 & 12050 & 663000 \\
\hline 2009-10 & 9450 & 15500 & 71000 & 81200 & 42200 & 76000 & 45300 & 501000 & 12050 & 663000 \\
\hline $2010-11$ & 9450 & 15500 & 71400 & 81200 & 42800 & 76000 & 45300 & 501000 & 12050 & 663000 \\
\hline 2011-12 & 9450 & 15500 & 71400 & 81000 & 42800 & 45000 & 45300 & 493800 & 12050 & 652000 \\
\hline 2012-13 & 9450 & 15500 & 71400 & 81000 & 42800 & 45000 & 42000 & 493800 & 12100 & 652000 \\
\hline 2013-14 & 9100 & 15800 & 45500 & 18000 & 42800 & 45000 & 42000 & 493800 & 12070 & 647700 \\
\hline 2014-15 & 9100 & 15800 & 45500 & 18000 & 32600 & 45000 & 40000 & 489000 & 12100 & 610000 \\
\hline 2015-16 & 9100 & 15800 & 46000 & 18000 & 32600 & 45000 & 40000 & 489000 & 12100 & 610000 \\
\hline 2016-17 & 9100 & 15800 & 46000 & 18000 & 32600 & 45000 & 40000 & 489000 & 12100 & 610000 \\
\hline
\end{tabular}

Source: Season and Crop report of department of statistics Jalna (2016) 
Table. 2 Percentage change in land utilization pattern of the state

\begin{tabular}{|c|l|c|c|c|c|c|}
\hline Sr. No & \multicolumn{1}{|c|}{ Category of Land } & $\begin{array}{c}\text { Triennium } \\
\text { ending } \\
\text { average 2002- } \\
\mathbf{0 3}\end{array}$ & $\begin{array}{c}\text { Percentag } \\
\text { e to total } \\
\text { area }\end{array}$ & $\begin{array}{c}\text { Triennium } \\
\text { ending } \\
\text { average } \\
\mathbf{2 0 0 9 - 1 0}\end{array}$ & $\begin{array}{c}\text { Percentag } \\
\text { e to total } \\
\text { area }\end{array}$ & $\begin{array}{c}\text { Percentage } \\
\text { change }\end{array}$ \\
\hline $\mathbf{1}$ & Forest & 10100 & 15.23 & 9100 & 14.91 & -9.90 \\
\hline $\mathbf{2}$ & $\begin{array}{l}\text { arren and uncultivable } \\
\text { land }\end{array}$ & 14400 & 1.79 & 15800 & 1.95 & 9.7 \\
\hline $\mathbf{3}$ & $\begin{array}{l}\text { Land under non- } \\
\text { agricultural use }\end{array}$ & 71200 & 10.73 & 45800 & 7.50 & -35.67 \\
\hline $\mathbf{4}$ & Cultivable waste land & 80900 & 9.38 & 58000 & 9.50 & -28.30 \\
\hline $\mathbf{6}$ & Permenant pastures land & 41100 & 6.19 & 32600 & 5.34 & -20.68 \\
\hline $\mathbf{7}$ & Current fallow & 84000 & 12.66 & 45000 & 7.37 & -46.42 \\
\hline $\mathbf{8}$ & Other fallow & 48500 & 7.31 & 40000 & 6.55 & -17 \\
\hline $\mathbf{9}$ & Net sown area & 531000 & 80.09. & 489000 & 80.16 & 7.90 \\
\hline $\mathbf{1 0}$ & $\begin{array}{l}\text { Area sown more than } \\
\text { once }\end{array}$ & 132000 & 19.90 & 121000 & 19.83 & -8.33 \\
\hline $\mathbf{1 1}$ & Gross cropped area & 663000 & 85.76 & 610000 & 78.91 & -7.99 \\
\hline $\mathbf{1 2}$ & Total area & 773000 & 100 & 773000 & 100 & 00 \\
\hline
\end{tabular}

Table.3 Growth rate of land utilization pattern

\begin{tabular}{|c|l|c|c|c|c|c|c|}
\hline Sr. No. & \multicolumn{1}{|c|}{ Particulars } & \multicolumn{3}{|c|}{ LGR } & \multicolumn{3}{c|}{ CGR } \\
\hline $\mathbf{1}$ & Forest & -39.17 & 13.19 & 3.05 & -38.23 & 24.13 & III \\
\hline $\mathbf{2}$ & $\begin{array}{l}\text { Barren and } \\
\text { uncultivable land }\end{array}$ & 0.81 & 0.36 & 0.85 & 0.79 & 0.36 & 0.86 \\
\hline $\mathbf{3}$ & $\begin{array}{l}\text { Land under non- } \\
\text { agricultural use }\end{array}$ & -0.05 & -8.25 & -3.08 & -0.05 & -8.03 & -3.39 \\
\hline $\mathbf{4}$ & $\begin{array}{l}\text { Cultivable waste } \\
\text { land }\end{array}$ & 0.06 & -24.27 & -7.68 & 0.06 & -24.94 & -11.13 \\
\hline $\mathbf{5}$ & Permanent pastures & 0.47 & 0.25 & 0.36 & 0.50 & 0.23 & 0.44 \\
\hline $\mathbf{6}$ & $\begin{array}{l}\text { Land under misc } \\
\text { trees, grooves not } \\
\text { included in area } \\
\text { sown }\end{array}$ & -4.74 & 7.74 & 1.66 & 4.55 & 8.11 & 1.50 \\
\hline $\mathbf{7}$ & & & & & & \\
\hline $\mathbf{8}$ & Current fallow & 14.92 & 19.04 & 14.00 & 15.93 & 23.27 & 15.06 \\
\hline $\mathbf{9}$ & Other fallow & 0.57 & 12.25 & 7.33 & 0.57 & 14.54 & 6.97 \\
\hline $\mathbf{1 0}$ & Net sown area & 0.15 & -1.14 & -0.46 & 0.15 & -1.14 & -0.47 \\
\hline $\mathbf{1 1}$ & $\begin{array}{l}\text { Area sown more } \\
\text { than once }\end{array}$ & -0.94 & -0.12 & -0.88 & -0.97 & -0.09 & -0.87 \\
\hline *ross cropped area & 0.05 & -1.21 & -0.51 & 0.05 & -1.20 & -0.52 \\
\hline **agnificant at 5 per cent & & & & & & \\
\hline
\end{tabular}


The analysis of factors affecting the extent of fallow lands at the farm level using crosssection data reveals that increase in farm size, non-agricultural income and labor shortage have strong positive impact on the extent of fallow lands, while the credit availability and irrigation facilities are found to reduce the extent of fallow lands at the farm level. Another important measure is the institutional reform to ensure the prevention or regulation of converting fertile agricultural lands for non-agricultural purposes is another important mechanism to stabilize the net sown area. Conversion for non-agricultural purposes appears to be the most important threat to the common property land resources such as cultivable wastelands, land under miscellaneous tree crops and groves and grazing lands.

\section{References}

Deka, N., and Hajarika, J.P (2018). Changes in land use pattern and cropping pattern in Assam an Economic Analysis. Economic Affairs 63 (1): 3943

Adhikari, A., and Sekhon, M.K. (2014). An economic analysis of land use dynamics in Punjab. International Journal of Advanced Research. 2 (5): 551-560.

Meenakshi, R., and Indumathy, R. (2009). Land utilisation and Cropping pattern in Tamil Nadu. Indian Journal of Agricultural Economics. 64 (1): 144153.

Bardhan, D., and Tewari, S.K. (2010). An investigation into land use dynamics in India and land under-utilisation. Indian Journal of Agricultural Economics. 65 (4): 658-676.

\section{How to cite this article:}

Kharat, A.A., K.V. Deshmukh and Shelke, R.D. 2019. Growth Action of Land Utilization Pattern in Jalna District of Maharashtra State, India. Int.J.Curr.Microbiol.App.Sci. 8(05): 18571862. doi: https://doi.org/10.20546/ijcmas.2019.805.217 